\title{
Customers Perception on Service Quality and Satisfaction Level in Historical Tourist Destinations: A Case of Eastern Zone of Tigray
}

\author{
Haftu Kidanemariam \\ Departemet of Managemnt, College of Business and Economics, Adigrat University, Ethiopia
}

*Corresponding Author: Haftu Kidanemariam, Departemet of Managemnt, College of Business and Economics, Adigrat University, Ethiopia Email: haftuk.m03@gmail.com

\begin{abstract}
For economic development, tourism sectors play a great role for countries like Ethiopia. As international tourism continues to develop from time to time, it is necessary to maintain the tourism sector for generations. Consequently, qualified tourist destination becomes one of the best tools to satisfy customers. The purpose of this study is to assess customer perception on service quality and their satisfaction level in tourist destinations. This study was used the five dimensions of SERVQUAL model, namely; tangibility, reliability, responsiveness, assurance, and empathy having 22 attributes to measure service quality Gap between expectation and perception using likert scale in tourist destinations. Cross sectional study is conducted using convenience sampling technique from a total of 123 respondents. The collected data was analyzed using gap analysis method to the mean difference between perception and expectation of each service quality dimensions. Findings showed that the empathy dimension scored high in terms of customer expectation but it scored the last in perception after the actual experience of the customers. This creates high negative mean gap in service quality between expectation and perception. Generally in three dimensions; empathy, tangibility and responsiveness scored negative and the remaining two scored positive mean gaps. Furthermore the aggregate mean gap between perception and expectation is negative. The negative gaps represent expectation is higher than perception and a reverse is true for positive gaps. Paired t-test was applied to test the significant difference between expectation and perception in each attributes. Hence, seven attributes was found insignificant which represents as good sides of the destination and the remaining showed that significant difference which are a weak sides. To conclude, customers' expectations have somehow exceeded from the actual perceptions and have an effect on the overall satisfaction of customers. Finally, it recommended that the destinations have to focus on the negative gap attributes in each dimension which show significant difference between mean of expectation and perception so as to improve the service quality and to enhance the satisfaction of customers.
\end{abstract}

Keywords: Expectation, Perception, Destinations, Service Quality, Gap

\section{INTRODUCTION}

\subsection{Background of the Study}

Tourism is one of the highest and fastest growing sectors in the world; its role is a very important in the economy and inspired the growth of other economy (Osman and Sentosa, 2013). On 25 June 2015, the European Council for Tourism and Trade (ECTT) based in Romania, unanimously selected Ethiopia as the World Best Tourist Destination for 2015 and favorite cultural destination for 2015.

Tigray region has plenty more, older ones, with more paintings, special architecture; remote locations over 125 rock hewn churches are recorded with Tigray-alone. Most of them are visited around the Gheralta chained mountains, (Villages Ethiopia tour and travel, retrieved 16/10/2016). Understanding these element or components of the industry, especially the tourists, is vital to its overall success. Sharpley (2006) said that travel and tourism starts with the tourist. A successful marketing of a destination and its competitiveness involves an understanding of the impressions formed by the tourists about that destination (Clerides and Pashourtidou, 2007).

Measuring of customer satisfaction in tourist destination has a huge importance from this perspective. A successful judgment of customer satisfaction enhances competitiveness, encourages product 
differentiation, increases customer retention as well as positive word of mouth communication (Yuksel and Rimmington, 1998).

The measurement of service quality provides an important feedback for stakeholders to evaluate and improve the services to the tourists. Any service improvement programs that do not take tourists' expectation on the quality of service the country offered and delivered into consideration will not achieve its objectives (Lam, 2000). According to Abudu (2013), to remain competitive the stakeholders should assess the quality of service they are currently delivering. Lovelock \& Wirtz (2004) also believed that perceived service quality is only one component of customer satisfaction and it is based on the difference between consumers' expectations and perceptions of service.

Tourists want to spend their money to get the right and equivalent quality service to that amount (Ryan, 2005; Pender, 2005). However, in the study area there is no qualitative data gathered from tourists to assess their expectation, perception and satisfaction levels on the quality of service. In line with this according to World Bank, (2006) almost no attempt is made to study and measure the level of tourist satisfaction in Ethiopia. But according to different literatures, the only way to success in business is through satisfying the customers.

Hence, this study believes that there is a huge gap of data that can be used as measure of tourist destination's performance of service quality from the perspective of the tourists. Researching on the tourist satisfactions is therefore needed to be able to respond to these necessities, especially in countries like Ethiopia specifically to the eastern districts of Tigray region which is a rich in tourism destinations. Consequently this study had been assessed the customer's perception on service quality and their satisfaction level using the five dimensions of SERVQUAL models which are tangibility, reliability, responsiveness, assurance and empathy.

\section{OBJECTIVE OF THE STUDY}

\subsection{General Objective}

The general objective of the study is to assess customers' perception on service quality and satisfaction level in historical tourist destination of eastern zone of Tigray region.

\subsection{Specific Objectives}

- To assess the customer's expectation towards the service quality of the tourist destination

- To evaluate the customer's perception on the service quality of the destination

- To compare the extent of service quality of perception from expectation

- To evaluate the significant gap between perception and expectation of customers in each attributes

- To assess the overall customer's satisfaction with the service quality

\subsection{Conceptual Frame Work of the Study}

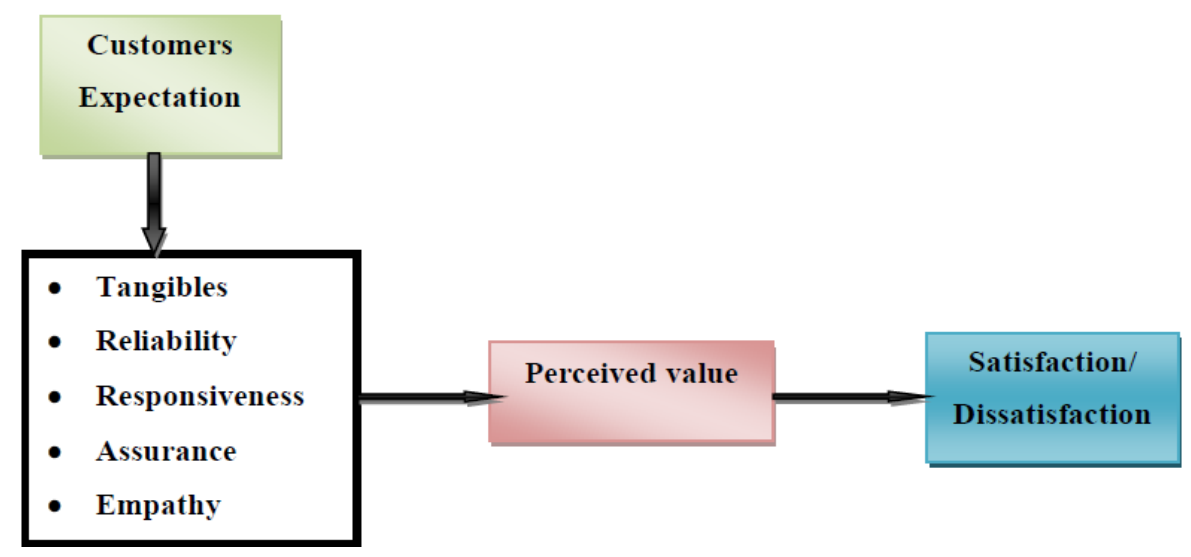

Source: Own development 


\subsection{Scope and Limitation of the Study}

The study focused on customer's perception on service quality in historical tourist destination of Eastern zone of Tigray specifically at the most historical places which are Hawzien and Wukro districts. This study considered all tourists together, focusing on those who come to visit the historical place and consume the tourism services and have knowledge about what they answer about it. The time horizon of the study was conducted at high tourist flow season (winter and spring). This study deals with the three factors; customers' expectation, perception on service quality and satisfaction.

This study obtained on cross sectional data. Furthermore the study is conducted only in eastern Tigray in two districts. But it was better to study in national level.

\section{MeTHOdOLOGY}

\subsection{Research Design}

In this study the descriptive survey method, specifically the cross sectional design was used. This method is a well known research design when the purpose of the study is to describe the characteristics of a certain group (Shukla, 2010). The study had been measured the tourism quality gaps between customer expectation and perception. SERVQUAL model was used to measure tourism service quality based on the five fundamental service quality dimensions. This study applied the five tourism service quality dimensions questionnaire which is formally developed by other marketing researchers.

\subsection{Population and Sample}

The population of the study was tourists who visit the historical places in the study area and those who used the services of the tourism destination in the study area. In this study there was no accurate documentation that represent about the number of population during the time of the research conducted. Here according to malhotra (2006), if the number of population is unknown, the researcher should be take arbitrarily 150 respondents as a sample. Therefore based on this justification, 150 tourist customers had taken as a sample and selected based on convenience sampling method.

\subsection{Types of Data and Sources}

Qualitative data were collected from primary sources because it is better to collect data directly from the customers. These data were collected from the respondents through SERVQUAL model questionnaire which is formally prepared and accepted by other marketing researchers.

\subsection{Method of data Collection and Instruments}

Formally standardized and prepared questionnaire with some modification was used and distributed to the targeted sample. The survey was conducted from April 1 up to May15 / 2016. It is concentrated on the customers' expectation, perceptions and customers' overall satisfactions of the service quality on the same 5-point Likert scale starting ranged from "highly agree" which take score 1 to "highly disagree" which taken score 5. Data was collected from attraction sites and destinations in Hawzien and Wukro.

\subsection{Methods of Data Analysis}

After collecting the necessary data, it was coded, tabulated, and analyzed using SPSS version 20 software and then, interpreted using descriptive statistics, like frequency, percentage, mean and standard deviation. Paired t-tests were used to test significant differences between the means of expectations and perceptions.

\section{RESUlt AND DisCuSSION}

\subsection{Expectation and Perception of Tourist Destinations}

Table1. Tourists Expectation, Perception and Mean Gaps

\begin{tabular}{|l|l|l|l|l|l|l|l|l|}
\hline \multirow{2}{*}{ Dimension } & \multicolumn{2}{l|}{ Perception } & \multicolumn{2}{l|}{ Expectation } & \multicolumn{2}{l|}{ Gap } \\
\cline { 2 - 9 } & Mean & SD & Rank & Mean & SD & Rank & Mean & Rank \\
\hline Tangibility & 2.945 & 1.148 & 4 & 3.4675 & 0.83525 & 4 & -0.5225 & 2 \\
\hline Reliability & 3.5 & 1.0854 & 2 & 3.354 & 0.9104 & 5 & 0.146 & 5 \\
\hline Responsiveness & 3.23 & 1.1875 & 3 & 3.4975 & 0.9005 & 3 & -0.2675 & 3 \\
\hline Assurance & 3.575 & 1.2925 & 1 & 3.5525 & 0.89075 & 2 & 0.0225 & 4 \\
\hline Empathy & 2.806 & 1.2782 & 5 & 3.596 & 1.0304 & 1 & -0.79 & 1 \\
\hline Aggregate mean & $\mathbf{3 . 2 1 1 2}$ & $\mathbf{1 . 1 9 8 3 2}$ & & $\mathbf{3 . 4 9 3 5}$ & $\mathbf{0 . 9 1 3 4 6}$ & & $\mathbf{- 0 . 2 8 2 3}$ & \\
\hline
\end{tabular}


Source: SPSS result (2016)

As the below table, concerning to expectation, empathy dimension of service quality had been ranked first and the second, third, fourth and fifth is assurance, responsiveness, tangibility and reliability respectively.

With regard to actual experiences of perception, it has been obtained that assurance dimension was ranked first and reliability, responsiveness, tangibility and empathy dimensions were ranked second, third, fourth and fifth respectively.

Gap analysis result indicates tourists actual service experience was less than their expectation along with three service quality dimensions. Hence the gap is negative in those dimensions. The aggregate mean difference between expectation and perception in general was negative. The wider gap is observed in empathy dimension. These shows the destinations can't able to meet the expectation of the customers. The positive gap is also observed in reliability and assurance. Generally the negative gaps are higher than positive gaps. Therefore, the tourist destination is expected well by the customers.

\subsection{Paired Sample T-test}

Table2. Significance Gap Level between Expectation and Perception of each Attributes

\begin{tabular}{|c|c|c|c|c|c|c|c|}
\hline \multirow[t]{2}{*}{\begin{tabular}{|l|l} 
No & Service Quality Dimensions
\end{tabular}} & \multicolumn{2}{|c|}{ Perce } & \multicolumn{2}{|c|}{ Expectation } & \multirow{2}{*}{$\begin{array}{l}\text { M. } \\
\text { Gap }\end{array}$} & \multirow{2}{*}{$\begin{array}{l}\text { t- } \\
\text { value }\end{array}$} & \multirow{2}{*}{$\begin{array}{l}\text { Sig.2 } \\
\text { tailed }\end{array}$} \\
\hline & $\mathbf{M}$ & SD & $\mathbf{M}$ & SD & & & \\
\hline \multicolumn{8}{|l|}{ Tangibles } \\
\hline 1. The destination has modern-looking equipment & 2.97 & .966 & 3.37 & .890 & -0.4 & 3.250 & .001 \\
\hline 2. The physical facilities are visually appealing & 3.46 & 1.23 & 3.59 & .829 & -0.13 & 3.926 & .356 \\
\hline 3. Employees are neat-appearing & 2.84 & 1.15 & 3.43 & .840 & -0.59 & 4.601 & .000 \\
\hline 4. Materials associated with the service are visually appealing & 2.51 & 1.19 & 3.48 & .782 & -0.97 & 77.957 & .000 \\
\hline \multicolumn{8}{|l|}{ Reliability } \\
\hline 5. The destination finish its activities on time & 4.08 & .911 & 3.5 & .881 & 0.58 & -5.60 & .000 \\
\hline $\begin{array}{l}\text { 6. When customer has a problem, the destination shows a } \\
\text { sincere interest in solving it }\end{array}$ & 3.59 & 1.29 & 3.45 & .951 & 0.14 & -1.04 & .297 \\
\hline 7. The destination performs the service right the first time & 3.95 & .913 & 3.36 & .897 & 0.59 & 5.865 & .000 \\
\hline $\begin{array}{ll}\text { 8. Services are provided at the time the destination promises to } \\
\text { do }\end{array}$ & 3.02 & 1.149 & 3.24 & .959 & -0.22 & 1.623 & .107 \\
\hline 9. The ordering records are error-free & 2.86 & 1.16 & 3.22 & .864 & -0.36 & 3.419 & .001 \\
\hline \multicolumn{8}{|l|}{ Responsiveness } \\
\hline 10. Employees tell customers when services will be performed & 2.96 & 1.20 & 3.40 & .981 & -0.44 & 2.772 & .006 \\
\hline 11. Employees give prompt service to customers & 3.99 & 1.13 & 3.49 & .900 & 0.5 & 4.543 & .000 \\
\hline 12. Employees are willing to help customers & 3.27 & 1.27 & 3.56 & .898 & -0.29 & 2.337 & .021 \\
\hline $\begin{array}{l}\text { 13. Employees are never too busy to respond to customer's } \\
\text { requests }\end{array}$ & 2.70 & 1.14 & 3.54 & 823 & -0.84 & 6.402 & .000 \\
\hline \multicolumn{8}{|l|}{ Assurance } \\
\hline 14. The behavior of employees instill confidence in customers & 3.60 & 1.29 & 3.51 & .961 & 0.09 & -.701 & .484 \\
\hline 15. Customers feel safe in their transactions & 3.34 & 1.42 & 3.50 & .909 & -0.16 & 51.197 & .234 \\
\hline 16. Employees are consistently polite & 3.77 & 1.18 & 3.60 & .837 & 0.17 & -1.33 & .184 \\
\hline $\begin{array}{l}\text { 17. Employees have the knowledge to answer customer's } \\
\text { questions }\end{array}$ & 3.59 & 1.28 & 3.60 & .856 & -0.01 & .122 & .903 \\
\hline \multicolumn{8}{|l|}{ Empathy } \\
\hline 18. The destination gives individual attention to the customer & 3.19 & 1.29 & 3.46 & .978 & -0.27 & 2.036 & .044 \\
\hline 19. Employees give personal attention to customers & 3.16 & 1.35 & 3.71 & 1.01 & -0.55 & 3.837 & .000 \\
\hline 20. The destination understands specifics needs of its customers & 2.71 & 1.39 & 3.57 & 1.11 & -0.86 & 5.654 & .000 \\
\hline 21. The destination has customer's interest at heart & 2.47 & 1.24 & 3.67 & .964 & -1.2 & 8.760 & .000 \\
\hline 22. Operating hours are convenient to all customers & 2.50 & 1.11 & 3.57 & 1.08 & -1.07 & 77.824 & .000 \\
\hline
\end{tabular}

Source: SPSS result (2016)

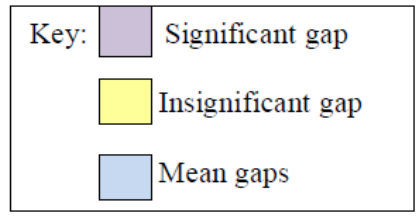




\subsection{Notes:}

- T-test two- tail with probability $<0.05$.

- A mean Gap=Perception Mean - Expectation Mean

- $\mathrm{M}=$ Mean

- $\mathrm{SD}=$ standard deviation

- Significant gap $(p<0.05)$

From the above 22 measured attributes, the five least rated gaps were reported on the following attributes; Employees knowledge to answer customer's questions, behavior of employees inspire confidence in customers, visual appeal of physical facilities, customer's problem solving, customers safety in transactions.

To the reverse the following five attributes are top rated in terms of reported gaps: The destination's customer interest at heart, operating hours, materials visual appeal, understanding specific needs of customers and employees respond to customer's requests. These indicate customers did not perceive as their expectations.

\subsection{Overall Customer Satisfaction}

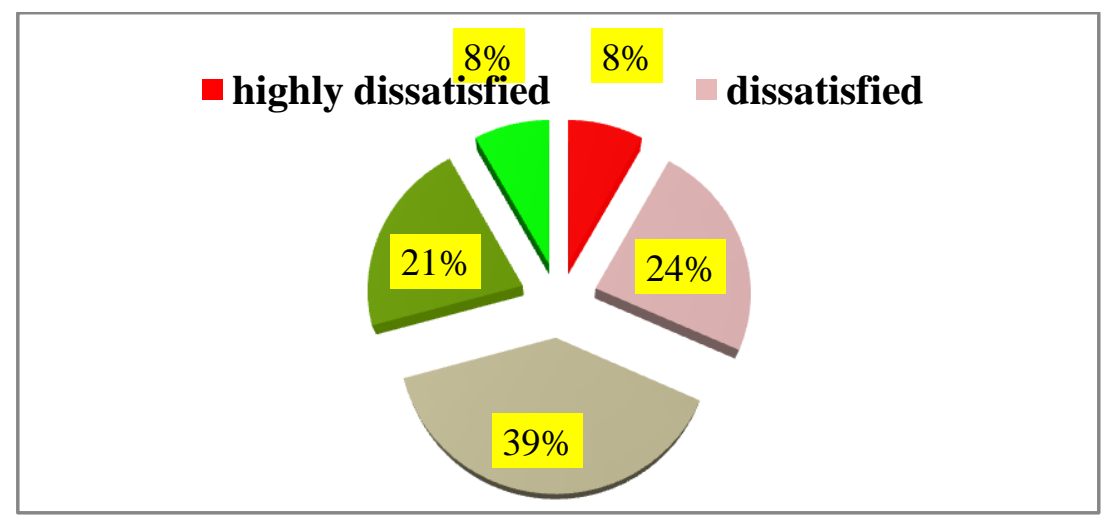

Figure1. Overall Satisfaction Levels of Customers

Source: own survey 2016

Table3. Satisfaction Mean

\begin{tabular}{|c|c|c|}
\hline & $\mathbf{N}$ & Mean \\
\hline Overall Satisfaction & 123 & 2.98 \\
\hline
\end{tabular}

Source: SPSS output (2016)

In regard to tourists overall satisfaction level, most of respondents were observed under neutral. The lowest percentages (16\%) are under highly dissatisfied and highly satisfied in equal proportion. But when satisfied and dissatisfied are compared each other, dissatisfied is slightly better. Furthermore, mean score shows 2.98 .

\section{CONCLUSION}

Coming to the main point of discussion in the study, the first specific objective is about customers' expectation from tourist destination's service quality. Thus, it has been found customers expectation based on the five point likert scale for each five service quality dimensions was rated from the highest empathy to the lowest reliability. Therefore, tourist destinations were expected well by the customers.

The next point of analysis was about the customers' perception and found that the mean values obtained from five service quality dimensions range from the highest assurance, to the lowest empathy. The third point is to measure the service quality gap from expectation and perception. Hence according parasuraman et.al 1985, the service quality gap score is calculated by "perceptionexpectation". Through the application of this formula, the result is ranged from the highest empathy to the lowest reliability. Therefore, the customers' expectations are not meet actual service quality in the destinations. 
From the significant gap difference between all attributes of the expectation and perception, the paired t-test result shows, seven attributes were reported their $\mathrm{p}$-value was greater than 0.05 . Therefore mean difference between perception and expectation in these attributes is not significant. These are found 4 attributes in assurance, 2 in reliability and 1 in tangibility dimension. Hence, mean gaps of all attributes in assurance are insignificant and shows there are no more gaps in mean value of perception and expectation. In the remaining 15 attributes their $\mathrm{p}$ - value was found less than 0.05 . This indicates there is significant difference between mean of expectation and perception and shows high mean gap of expectation and perception.

Insignificant difference denotes strong sides of the tourist destination service quality because low gap in this sense is a sign of good service quality management, whereas the significant difference stands for weak side of the destinations service quality because high negative gap is a sense of low service quality management in the destination. Therefore the lowest gap scores like the attributes of assurance, and one attributes of tangibility and reliability are good sides of the destination, while the highest gap score attributes like the three attributes of empathy, one attribute of each tangibility and responsiveness are a sense of weak sides by the destination.

The tourist overall satisfaction implied that they are around neutral, but slightly inclined to dissatisfaction. The main reason for this is due to the negative gap of expectation and perception. But even if there is a negative gap between perception and expectation, it is not equal with the difference of satisfaction mean from the average (neutral). This means the negative gap does not proportionally affected to the overall satisfaction, rather slightly they was satisfied with what they saw and experience. Most of the time such phenomenon is encountered in SERVQUAL studies (Rute \& James, 1991).

\section{RECOMMENDATION}

Looking on the result and discussions made, the subsequent recommendations were suggested to fill service quality gaps. Primarily the stake holders has recommended to give maximum attention for those have highest gap scores in perception and expectation in each attributes like the attributes of empathy, i.e. the destination has been better to give individual attention to each customers, the employees of the destination have to understand specific needs of its customers, show the customer's interest at heart and the operating hours have to be convenient to all customers to meet their expectation.

Similarly the second wider service quality gap is in tangibility dimension. Hence, the stakeholders of tourist destination had recommended to access materials which visually appealing with modernlooking equipment that feels disclosure to the customers. Employees are supposed to always neat appearing to the customers. Furthermore waiters should have enough knowledge and speaking skill to be responsive to all questions raised by the customers.

For the lowest gap attributes, which they represent the good sides of the destination has not to neglect by the stakeholders, rather strictly follow and improve it to be sustainable for the future. In order to improve service quality, it is necessary to contact employees regularly and assess their service experiences. Like the external customer, internal customers have to consider categories of service attributes, such as empathy, tangibility and responsiveness, in judging the quality of the internal service.

\section{REFERENCE}

[1] Abudu, K. (2013). Tourist destination competitiveness in sustainable tourism in Ethiopia Unpublished Master's Thesis, Addis Abeba University School of Commerce

[2] Christine T. Ennew, Geoffrey V. Reed \& Martin R. Binks. (1993). Importance performance analysis. European Jornal of Marketing, 27(2), 59-70.

[3] Clerides, S. \& Pashourtidou, N. (2007) Tourism in Cyprus: Recent trends and lessons from the tourist satisfaction survey. Cyprus Economic Policy Review, 1(1), 51-72.

[4] Cristina Jonsson \& Dwayne Devonish. (2008). Does nationality, gender, and age affect travel motivation? A case of visitors to the Caribbean Island of Barbados. Journal of Travel and Tourisn Marketing, 25(3-4), 398-407. 
[5] Lam,E. (2000). Service quality assessment scale: An instrument for evaluating service quality of health fitness clubs. A dissertation at University of Houston, Ann Arbor: Bell \& Howell information and learning center.

[6] Lovelock, C. and Wright, R. (2004). Principles of Service Marketing and Management, Prentice-Hall, Upper Saddle River, NJ

[7] Malhotra,N.K. (2006). Marketing research: an applied orientation. $2^{\text {nd }}$ ed, new jersey, prince-hall international .Inc.

[8] Osman, Z. \& Sentosa, I. (2013). Mediating effect of customer satisfaction on service quality and customer loyalty relationship in Malaysian rural tourism, International Journal of Economics and Management Studies, 2(1), 25-37

[9] Parasuraman, A., Zeithaml, V. A., \& Berry, L., L. (1988). SERVQUAL: A Multiple-item scale for measuring consumer perception of service quality. Journal of Retailing, 64(1), 12-40.

[10] Rute, N.B., James, H.D. (1991). A multi modal of consumers' assessment of service quality and value, Journal of consumer research, 17(4):375-384.

[11] Ryan, C. (2005). The Management of Tourism: Site and visitor management at natural attractions, SAGE Publications Ltd

[12] Sharpley R. (2006) Travel and Tourism. New Delhi: Sage Publications India Pvt. Ltd.

[13] Shukla. (2010). Effects of perceived sacrifice quality value and satisfaction on behavioral intentions in the service environment: Services Marketing, Quarterly, 31, 466-484

[14] Sonia khan. (2011). Genderd leisure: are womens more consentrated in travel for leisure?. an international multi deciplinary journal of tourism, 6(1), 105-121.

[15] World Bank. (2006). Ethiopia in Mekeda's Footsteps: Towards a strategy for pro-poor tourism development

[16] Yuksel A. Rimmington M. (1998). Customer-Satisfaction Measurement: performance counts. Cornell Hotel and Restaurant administration quarterly, 39(60)

Citation: Haftu Kidanemariam. "Customers Perception on Service Quality and Satisfaction Level in Historical Tourist Destinations: A Case of Eastern Zone of Tigray " International Journal of Managerial Studies and Research (IJMSR), vol 6, no. 1, 2018, pp. 49-55. doi:http://dx.doi.org/10.20431/23490349.0601007.

Copyright: (C) 2017 Authors. This is an open-access article distributed under the terms of the Creative Commons Attribution License, which permits unrestricted use, distribution, and reproduction in any medium, provided the original author and source are credited. 